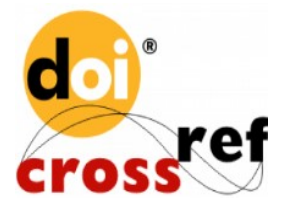

Social Informatics, Business, Politics, Law \& Technology Journal

An International Pan-African Multidisciplinary Journal of the SMART Research Group International Centre for IT \& Development (ICITD), Southern University Baton Rouge, LA, USA

(c) Creative Research Publishers - Available online at https://www.isteams.net/socialinformaticsjournal DOI: dx.doi.org/10.22624/AIMS/SIJ/V6N1P3

CrossREF Member Listing - https://www.crossref.org/06members/50go-live.html

\title{
"Muzarah" Share-Cropping and "Musagah" Irrigation as Methods of Partnership for Financing Agricultural Sector and Micro Finance Projects Practiced by Islamic Banks.
}

\author{
Ahmed El-Murdi Saeed Omar \\ Professor, Department of Islamic Studies, \\ Faculty of Shariah and Islamic Sciences \\ University of Alwasl \\ Dubai, United Arab Emirates \\ Email: ahmedelmurdi@yahoo.com/ ahmedelmurdi@gmail.com
}

Phone: 00971504751430

\begin{abstract}
In this paper, the researcher expected to explain provisions of Islamic financial jurisprudence in respect to the related and selected commercial contracts and to relate their implantation to Islamic Banking system. The objectives are to tell the reader: (1) how the pioneer Muslim scholars compiled and documented the provisions of Muzarah and Musagah as essential methods for partnership recently in Islamic Banking systems. The researcher adopts the APA style that is well known method for referencing to evaluate literature. Findings from the research showed that (1) Sharing corps is a contract allowed within Hanbali School of thought and in the view of Abu Yousuf and Mohammed bn Al-Hassan Alshybaini. (2) for the validity of share cropping conditions of: The land that should be cultivated, the seeds, the employees, the profit and the duration of the contract should be well stated. (3) Share cropping could be valid or vitiated. (4) The contract of Musagat or irrigation will be formed by offer and acceptance. (5) Contract of irrigation is handling tree to workers for purpose or irrigation or harvesting. (6) Contract of Musagah and Muzarah sharing the same conditions. (7) Both of the contracts bearing the same reasons of void or invalidity. The researcher recommends that relevant academic area of knowledge in particular Department sof: economics, banking and finance, law, Islamic Sciences, Business and Management to include the Islamic methods of investment in business, in their curriculums and syllabus at both undergraduate and postgraduate levels.
\end{abstract}

Keywords: "Muzarah", Share-Cropping, "Musagah", Irrigation, Partnership, Financing, Agricultural Sector, Micro Finance, Projects, Islamic Banks. 


\section{INTRODUCTION}

By the forgoing proposed paper the researcher will define conventional and Islamic Banks, explaining their functions, methods of investment, provisions of Muzarah (share cropping and Musagah (Irrigation) as commercial Islamic Contracts, the role of Islamic bank to finance this type of partnership and their legal frame work.

Although recently Islamic bank practicing various types of partnership such as; Mufawada partnership or company of negotiation, Mudaraba partnership or company of bargaining, and partnership of Mufawada that company of professionals in addition to Muzara'ah and Musaqah. Therefore the paper suggesting the presentation to include five semi parts to be as follows;-

Part (1): Definition of conventional banks and Islamic bank, methods of partnership in Islamic Bank and their functions.

Part (2): Provisions' of "Muzara'ah" share cropping as method of partnership in Islamic banks.

Part (3): Provisions of "Musaqah" irrigation as method of partnership in Islamic bank.

Part (4) Legal framework or share cropping and irrigation according to provisions of Islamic act of Sudanese business law of transaction, 1984.

Part (5): The role of Islamic bank in respect of practicing Musara'ah and Musaqah.

Part (1): Definition of conventional banks and Islamic bank, methods of partnership in Islamic Bank, their functions, the legal framework of Islamic Banks in Nigeria and Islamic Financial Institutions in Nigeria (a)Definition of conventional banks:

Economists have defined a bank in various capacities, some emphasizing its various functions. For instance, a bank has been defined as 'an organization whose principle operations are concerned with the accumulation of the temporary idle money of the general public for the purpose of advancing to others for expenditures, (Kent, R.P., 1961). Sayers in his book 'Modern banking gave a detailed definition of a bank thus; 'ordinary banking business consists of changing cash for bank deposits and bank deposits for cash; transferring bank deposits in exchange for bills of exchange, government bonds, the secured or unsecured promises of businessmen to repay, etc.'

Collins National Dictionary, defines a bank as an establishment where money is receive for custody and repaid on demand.' Summarizing all these definitions, a bank is simply an institution which accepts deposit from the public and in turn advances loans by creating credit'.

1E.S. EKEZIE- THE ELEMENTS OF BANKING- MONEY FINANCIAL INSTITUTION AND MARKETS, AFRICANA-FEP PUBLISHERS LIMITED, ZARIA 2002. P. 68. 
(b) Functions Of An Islamic Banks: The following main functions:

1. Current Deposit

2. Savings Bank Deposit

3. Investment Account or Investment Deposit

4. Deposits With Authorization

5. Deposits Without Authorization

6. Participation in the Establishment of Companies

7. Financing through Partnership

8. Qard Al-Hasan

9. The Zakah Fund

10. Other Banking Services

The Islamic Bank can also render the following services:

- $\quad$ Letter of Credit.

- $\quad$ Acceptance and servicing of certificates and shares.

- $\quad$ Foreign Exchange Transactions.

- $\quad$ Local and overseas guarantying.

- $\quad$ Renting safes for clients.

- $\quad$ Safe guarding personal belongings and security certificates, gold, precious stones, documents, etc.

- $\quad$ Investment trustee.

- $\quad$ Collecting claims and payment of periodical financial obligations on behalf of its clients.

- $\quad$ Representation of banks and similar institutions and correspondents operations.

- $\quad$ Accepting subscriptions in companies².

(c) The Legal Framework of Islamic Banks in Nigeria:

\section{Supervision and Control of Islamic Banks under the CBN Act:}

Aside from the powers to issue directives on cash reserve and special mentioned above, both the CBN Act and BOFIA sufficiently empowers the Central Bank to exercise supervisory and control function over every bank operating in Nigeria. Among such powers are the powers to issue guidelines, rules and regulations for the operations of banks or any institution engaging in financial services as well as enforcing the rules and regulations. Approval or disapproval annually of the appointment of the auditor by all banks; appoint director of banking supervision and remove ailing bank's manager, staff and directors. He can also order special examination or investigation of any bank if it is in the interest of the public to do so or upon an application of a director, shareholder, depositor or creditor of the bank.

Islamic or PLS bank is not and should not in any way be insulated from these supervisory and controlling powers of the central bank for the same reason of maintaining the public confidence in the financial system. Furthermore, one of the distinctive supervisory and controlling power of the Central Bank is its statutory right to subscribe to the shares of any bank in Nigeria. This provision is double edged. On one hand, it could assist the Islamic bank to generate the statutorily required financial resources for its establishment.

\footnotetext{
${ }^{2}$ M.A. Mannan, A.K.M FazlulHoque and R.Z: Functions of an Islamic Banks, Chapter 9, Edited in the book of Islamic Banking How Far Have We Gone, pp 121-125.
} 
On the other hand, the ownership of substantial equity shares of an Islamic bank by the Central Bank would enhance the control of the former by the latter and by necessary extension, an efficient control of the banking system ${ }^{3}$.

\section{Regulations made Pursuant to the Legislations:}

Pursuant to relevant provisions of the CBN Act, 2007 and BOFIA 1991 as amended, empowering the Central Bank Governor to make rules and regulations for the operation and control of all institutions under the supervision of the Bank, the CBN issued regulations for Non- Interest financial institution in Nigeria in January, 2011. although the frame work attracted a lot of criticism, particularly from the non-Muslim populace on allegation of promoting religious ideals in a 'secular state', nonetheless, it laid good foundation for a smooth take-off of Islamic financial system in Nigeria. The framework covers operations of full-fledge Islamic bank, Micro Finance Bank, non-interest subsidiary, window or branch of a conventional bank and non-interest mortgage and finance institutions. It also established the CBN Shari'ah Council (SCC) as advisory body on Shari'ah regulatory matter. Two guidelines have also been issued in support of the framework. All these regulations and guidelines paved ways for the issuance of the operating license to the first full-fledge Islamic bank in Nigeria in June, 2011.

Other relevant financial institutions regulatory agencies have also been taking similar steps to accommodate the newly adopted financial system. The Nigeria Deposit Insurance Corporation for instance, issued a draft framework for Non- Interest Deposit Insurance Scheme in August 2010. Similarly, the Security and Exchange Commission in the proposed amendment to its rules and regulations made provisions for Rules on Islamic Fund Management. The recognized Islamic Fund Management as well as the role of Shari'ah Adviser in relation thereto ${ }^{4}$.

\section{Islamic Banking and the Legal Environment in Nigeria:}

Usually banking is a highly regulated sector of the economy. Therefore, banks of whatever nature have quite a lot of laws, rules and procedures to comply with. The nature of legal system in a country often dictates the nature of laws and regulatory system for banks in any particular country. Bank in a common law country are regulated by common law as against Islamic law. For a successful introduction of Islamic banking in such a country the relevant laws must be examined with a view to identifying if there are windows within the existing laws which may permit such introduction or if the country is prepared to make or amend existing laws to accommodate the same.

Some of the laws regulating bank operation in Nigeria are hereunder examined with a view to seeing how much of the Islamic banking practice it can accommodate ${ }^{5}$.

1. The Banking Act 1969

2. $\quad$ Banks and Other Financial Institutions Act 1991 Act Cap. B 3 L.F.N. 2004.

3. The Central Bank of Nigeria Act 2007.

4. $\quad$ Economic and Financial Crime Commission (Establishment) Act, 2004.

5. $\quad$ Nigerian Deposit Insurance Corporation Act 2006.

\footnotetext{
${ }^{3}$ Abdullahi Ibrahim Abikan (2013): The Legal Framework of Islamic Banking In Nigeria, chapter 7, edited in the book of Essential of Islamic Banking and Finance in Nigeria, edited by K.I. Dandago A.D. Muhammad and U.O Useni, pp 112-114.

${ }^{4}$ Abikan I.B.D, p118.

${ }^{5}$ O.Y. Abdul (2013): Corporate Governance and Islamic Banking in Nigeria, Chapter 10, Edited in a book Essential of Islamic Banking and Finance in Nigeria, edited by K.I. Dandago A.D. Muhammad and U.O Useni, p160.
} 


\section{(d) Establishment of Shariah Advisory committee as part of the legal framework of Islamic Banks in Nigeria:}

An Islamic bank in Nigeria cannot but also be under the 'watchful eyes' of the Central Bank. However, as long as the country's economic system and the operations of the Central Bank are still interest oriented, certain difficulties are likely to be encountered on the relationship between the two banks by the provisions of the Act which require some exposition. Section 8.2 of the CBN framework for the Regulation and Supervision of Institutions offering NonInterest Financial Services in Nigeria 2010 mandates the establishment of Shari'ah Advisory Committee by each bank with a similar supervisory body, CBN Shari'ah Council constituted at the apex bank.

\section{(e) Microfinance Institutions briefly in Nigeria:}

The increasing rate of poverty coupled with the escalating growth in unemployment rate in Nigeria and its consequences on socio- economic stability prompted high concern for the government to intensify program that promote creation of small businesses in Nigeria. The Nigerian government has been playing active role in promoting private investment and small business since the 1960s. As part of the effort towards a conducive environment for the small business and private sector participation in the economy, the government of Nigeria introduced various program. Among the numerous programs introduced are, Structural Adjustment Program (SAP), Micro- Finance Policy (MFP), National Economic Empowerment and Development Strategy (NEEDS). Most of the programs are tailored towards the provision of private participation in the production activities through financial liberalization. The expectation was that, financial liberalization will facilitate the flow of funds for private and small business development. Factors such as political and economic instability and high cost of finance still remain the major impediment to the survival of small business in Nigeria, (Obamuyi, ND).

Scarcity of funds and high administrative cost has been identified as some of the problems facing small business establishment and sustainability in Nigeria (Ekpengong and Nyong, 1992; Dada, ND; Ayanda and Laraba, 2011). Due to the scarcity of funds and poor financial system, most micro- finance institutions charge exorbitant interest rate on their loans which hardly make it hard for the borrowers to maintain and sustain the business. This thus account for the failure majority of the small business in Nigeria. Cost of doing business especially cost for renting stall in most city in Nigeria discourage many people with business idea and innovation from starting their own business 6 .

The important role of small business in the economy cannot be underestimated. Studies have shown and proved the resilience nature of this type of business during the period of economic recession (Ayanda and Laraba, 2011).

\section{Part (2): Provisions' of "Muzara'ah" share cropping as method of partnership in Islamic banks according} to Islamic Jurisprudence:

In this section we will discuss the meaning of muzara'ah, its legal justification, elements, types, conditions and termination.

The meaning of Muzara'ah: (The farming):

\footnotetext{
${ }^{6}$ OladokunNafiuOlaniyi, Abdel Ghani Echchabi, Mohamad fanyAlfarisi, (2013): Sukuk as An-Internative Mechanism for Infrastructure Development and Improvement of Small Business in Nigeria, Chapter 13, Edited in a book Essential of Islamic Banking and Finance in Nigeria, edited by K.I. Dandago A.D. Muhammad and U.O Useni, p203.
} 
The jurists begin with an analysis of the term muzara'ah and discuss whether its grammatical form implies work by both partners, when in practice only one person does the work ${ }^{7}$.Al-Kasani verifying the use of the term as proper quotes a number of other terms that have similar grammatical forms, but involve work form one side ${ }^{8}$.

Technical, it means a contract for cultivation of land in return for part of the produce in accordance with the conditions stipulated by law9.the Majallah, in section 1413, defines it as follows: "Muzara'ah is a type of partnership with land contributed one party and work by another that is, the land is cultivated and yield is shared by them... ${ }^{10 "}$

\section{Legal justification of Muzara'ah: (Farming):}

We will begin with the position taken by the Hanafis along with the dissenting view of the founder of the school, Abu Hanifah. The views of the other schools will then follow.

\section{The Hanafi view:}

The Hanafi jurists disagreed about the contract of Muzara'ah with Abu Hanifah maintaining that it is not legally justifiable. Abu Yusuf and Muhammad Bin al-Shaybani held that it is legally maintainable. These two companions of Abu Hanifah argued as follows:

1. That the Prophet (peace be upon him) made the contract with the people of Khaybar for half of the produce, and this provides a precedent ${ }^{11}$.

2. It is a contract of partnership with wealth form one party and labor by the other, which is the same thing as Mudarabahon the basis of analogy (qiyas).

3. It is based on necessity. The owner of the land may not be in a position to cultivate the land himself, while the one who is able to work may not have land. Necessity, therefore, requires that they come to such an arrangement and conclude the contract.

4. The practice of the companions and their followers till this day has left precedents on which we many rely. Permitting Muzara'ah amounts to getting a rent for what is produced by the (personal) labour of the worker, and is similar to asking the miller to share the profit generated through milling, that is, purely his labour.

5. The transaction of the Prophet (peace be upon him) with the people of Khaybar was a type of Khara jimposed on them due to their submission and not a type of muzara'ah.

The fatwa, however, was given on the basis of the opinions of Abu Yusuf and al-Shaybani. The main reason was necessity and the practice of the people.

\section{Views of the Maliki School:}

\footnotetext{
${ }^{7}$ Al- Kasani, Bada'I' al-Sana'i', vol. 8 p.3807; al-Marghinani, al-Hidayah, vol. p. 53; al-zayla'i' Tabyin al-Haqa'iq, vol. 5, p. 278.

8Al-Kasani, Bada'I' Al-Sana'I', vol. 8, p. 3808.

9Majallat al-Ahkam al-adliyah, 1431.

${ }^{10} \mathrm{Ibn}$ 'Umar is reported to have said that the Prophet (peace be upon him made a Mu'amalah (agreement) with the people of Khaybar for a part of the yield of fruit and crops." This tradition is reported in the Sahih compilations. See al-Shawkani, Nayl al-Awtar, vol. 6, p.7

${ }^{11}$ Ibn Rushd, Bidayat al-mujtahid, vol. 2, p. 221.
} 
Ibn Rushd says that the Maliki opinion permits the renting of land for everything except food ${ }^{12}$.for this opinion he relies upon the same tradition about Mukhabarah that is relied upon by Abu Hanifah. The tradition proscribes the renting of land with its yield ${ }^{13}$. The Maliki jurists go into the details of the different types of Kira' (renting, leasing) of land ${ }^{14}$.Most of these are partnerships in tools, implements and land. The Muzara'ah proper that is permitted by the Hanafi school is not allowed by the Malikis.

\section{Views of the Shafi'i School:}

The Shafi' is maintain that Mukhabarah is not permitted. This, in their view, is a contract in which the seed is provided by the worker. They maintain that all the four schools consider it void ${ }^{15}$.

The Shafi'is permit Muzara'ah only when it is subservient to musaqah. In this case, there msut be some fruit bearing trees on the land or the land should be between two groves that are part of the contract of Musaqah. They justify this on the basis of the arrangement with the people of Khaybar ${ }^{16}$.

\section{Views of the Hanbali School:}

The views of the Hanbali school are similar to those of Abu Yusuf and al-Shaybani. They give identical arguments and even reproduce the arguments of necessity ${ }^{17}$.

THE CONCLUSION WE DRAW FROM THIS DISCUSSION is that Muzara'a $h$ proper is permitted by Abu Yusuf and Muhammad al Shaybani on the basis of necessity anchored in Istihsan. The Hanbali school follows these views without explaining the basis of their reliance. Abu Hanifah, Malik and al-Shafi'l consider Muzara'ahto be unlawful.

Rukn and Types: (Pillers of share cropping):

According to the Hanafis, Muzara'ahhas a single rukn and that is that sighah (offer and acceptance).

The types of Muzara'ah are as follows:

1. Land, implements, seed, and animals are provided by the landowner and work is undertaken by the tenant. This is permitted (by those who permit it as a whole).

2. Land is provided by the landowner and the rest of the things mentioned are provided by the tenant. This too is permitted by some.

3. Land and seed from the owner and the rest by the tenant. This too is permitted.

4. There are a number of other types in which the inputs are varied. Some of these are permitted by Abu Yusuf and some by Muhammad al-Shaybani ${ }^{18}$.

\section{Conditions validating the contract:}

12Ibid P. 222.

${ }^{13}$ Al-Dasuqi, Hashiyah, Vol. 3, p. 372; Shanun, Al mudawwanah al-kubra, vol.5, p. 52.

14Al-Ramli, Nihayat al-muhtaj, vol. 5, pp. 245-46.

15Al- RamliNihayat al-muhtaj, vol. 5 pp. 245-46.

16Loc. Cit.

17Ibn Qudamah, al-Mughni, Vol. 55, 418, 421.

${ }^{18}$ For the details of all these types see al-Kasani, Bada'I' al-Sana'I', vol. 8, pp.3816-18; al-Zayla'I, Tobyin al Haqa'iq Vol. 5, P. 278. 
The conditions validating the contract are either related to Muzara'ah itself, or to the seed, or to the profit, to implements, to yield, the land, and other to the duration of the contract. Some of these are summarized below ${ }^{19}$.

The conditions for the Muzari (or the farmer). These are two: first, that he should be sane.

Second, that he should not be an apostate. This view is derived on the principles laid down by Abu Hanifah.

The conditions for the Zar(or the farm). 'it should be clearly stated what is to be sown, that is, the seed, unless the landlord tells him to sow whatever type he likes.

The conditions for the Mazru' (or the plants). The product sown should be something useful and amenable to cultivation.

The conditions for the land (Mazru'fih).The land should be cultivable. It should be clearly delineated. It should be handed over the Muzari; that is, the owner should enable the worker to till the land and work on it.

The conditions for the provision of the seed. If the seed is provided by the tenant, he is the one who is hiring the land for the contract. If it is provided by the landlord, then, he is hiring the services of the tenant.

The duration of the contract. It is necessary to stipulate the duration for which the contract is made, otherwise it leads to Jahalah and disputes as to the sharing of the produce.

\section{Conditions vitiating the contract:}

Some of these are those that are contrary to the conditions validating the contract as mentioned above. There are others that pertain to the storage and preservation of the produce after the season. This work is not part of the Muzara'ah and may be done by the landlord.

The ahkam (legal effects) of Muzara'ah:

The legal effects are of three types: effects of a valid Muzara'ah;, effects of a fasid(unenforceable) Muzara'ah; and effects of a rescinded Muzara'ah ${ }^{20}$.

\section{The effects of a valid Muzara'ah:}

The valid Muzara'ahis a terminable contract ('aqd ghayr lazim) for the tenant, but is binding upon the owner of the land. If the tenant says to the landlord after the conclusion of the contract that he does not want to continue, he has the right to do so.

The work that is essential for the Muzara'ahlike cultivation and sowing is for the tenant to perform, while work that is not essential to it like transportation and harvesting is a joint liability. The produce is to be shared by both in accordance with the stipulated shares. If the land does not produce anything, then, there is nothing for either, and the tenant is not entitled to wages for his work nor is the landlord entitled rent for his land irrespective of who provided offering the seeds.

The effects of a vitiated Muzara'ah:

\footnotetext{
${ }^{19}$ These conditions have been reproduced from al-Kasani’s text. Ibid., vol. 8, pp. 3812-3822.

20Ibid., vol. 8, pp. 3822-3830
} 
The tenant has no obligation to perform any work in such a contract. The produced corps is entirely for the owner of the seeds, whether this was the tenant's or the landlord's. The other person will be provided reasonable wages or rent as the case may be. Reasonable rent- or wages are only due when there has been some utilization of the land, that is, if the land has been tilled and there is no production, the wages and rent are still due ${ }^{21}$.

\section{The effects of a rescinded Muzara'ah:}

Rescission may take place before the commencement of cultivation or after it. If it is rescinded prior to cultivation, there is nothing for the worker. If it is rescinded after cultivation and the land produces something and has been harvested, the production is to be shared by them as stipulated. 'If it has not been harvested, it is still to be shared by them along with the work that is left, and the tenant will be paid reasonable wages for this remaining work ${ }^{22}$.

\section{Rescission of the Muzara 'ah:}

If the Muzara'ah comes to an end either expressly or impliedly. Express termination is by faskh or iqalah (negotiated rescission). It is implied when the tenant is prevented from working on the land or when the period of the Muzara'ah is over.

The muzara'ah is-also terminated with the death of the tenant and the rights will pass to the heirs ${ }^{23}$. If the landlord dies the tenant will continue till the production is harvested and the new landlord cannot evict him ${ }^{24}$.

Part (3): Provisions of "Musaqah" irrigation as method of partnership in Islamic bank according to Islamic Jurisprudence.

In this section we will discuss the meaning of musaqah, its legal justification, elements and types, conditions and termination.

The meaning of Musaqah (or irrigation):

Technically, it is a contractor work for part of the produced along with the conditions of validity, ${ }^{25}$ " The author of alMughni says: "Musaqah is the giving of trees to another so that he undertakes to water them and performs all other associated work for a known part of their produced ${ }^{26}$. Al-Dasuqi says: "It is a contract for serving trees and whatever is associated with it for' part of the produced or for the whole lot of it27. The Majallah calls it "a type of sharikah so that the trees are contributed by one party and their care is undertaken by the other, with their-fruit being divided between them"28.

\footnotetext{
$21^{\text {Ibid.p. } 3825 .}$

$22^{\text {Ibid. p. } 3829}$.

${ }^{23}$ Ibid.p. 3828 .

${ }^{24}$ Majallah, §1440.

${ }^{25}$ AI-KasanI, Bada'i' al-\$ana'i', vol. 8, p. 3831.

${ }^{26}$ Ibn Qudamah, al-Mughni, vol. 5, p. 391.

${ }^{27}$ AI-DasuqI; al-hashiy,ah, vol. 3, p. 539.

${ }^{28}$ Almajalah, §1441.
} 


\section{Legal justification of Musaqah:}

The Hanafis disagreed about its validity on the same lines as in Muzara'ah with the same evidences and arguments. Abu Hanifah did not consider it valid, while his two disciples did ${ }^{29}$. Likewise, the Hanbalis permitted it in agreement with Abu Yusuf and al-Shaybani. According to the Malikis, Musaqah is permitted as an exemption from the following rules 30 :

1. ljarah with unknown wages;

2. $\quad$ Renting of land with what it produces;

3. Sale of fruit prior to the process of ripening, in fact, prior to its existence;

\section{The rukn (element) of Musaqah:}

The rukn (element) of musaqah is offer and acceptance. Thus, if the owner of the trees says to the worker: "I have delivered my trees to you by way of musaqah so that you may take such and such share from its fruit," and the worker accepts, then, the musaqah is formed ${ }^{31}$.

\section{The conditions of Musaqah}

Al-Zayla'i says that the conditions of musaqah differ from those of muzara'ah is four respects. He says:

The conditions of musaqah, in their view, are the same as those of muzara'ah except in four matters: First if either one of them refuses to perform the contract, he is to be forced to perform it as there is injury involved in it. This is different from the case of the owner of the seeds, who cannot be forced. Second, if the period is over, access to the trees is to be given without rent and' work is to be done without wages, and we will explain this in muzara'ah with wages.... Third, if a third party is entitled to the trees, the worker will be entitled to reasonable wages from such a party, while in muzara'ah the value of the crop is to be paid. Fourth, if the period needs to be determined, it will be presumed by way of istihsan as the season of the crop is well known ${ }^{32}$.

\section{Conditions specific to the parties:}

The parties to the contract must be sane. Bulugh (majority), however, is not a condition, and nor is freedom.

\section{Conditions specific to the stipulated shares}

According to al-Kasani the condition is that a share be stipulated for each one of the parties. If the entire yield is to be given to one party the musaqah is void ${ }^{33}$.

\section{Conditions specific to work:}

The primary work in this contract, is the watering of the trees, whether this is through wells or other means ${ }^{34}$.

\footnotetext{
${ }^{29}$ AI-Kasam, Badii i' al-\$anii.'i', vol. 8, p. 3831.

${ }^{30}$ IbnRushd, Bidiillat al-Mujtahid, vol. 2, p. 244; al-Dasuqi, al-hashiyah, vol. 3, p.539; al-Khirashi, Sharh alMukhtasar, vol. 6, p. 227.

${ }^{31}$ AI-KasanI, Bada'i' al-Sanai';', vol. 8, p.,3831j Majallah, §1442.

${ }^{32}$ AI-Zayla'I, Tabyyin al-Haqa'iq, vol. 5, p. 284.

${ }^{33}$ Loc. cit.

${ }^{34}$ lbnQudamah, al-Mughni, vol. 5, p. 3955 al-Kasani, Bada'i' al-Sana'i vol. 8, p.3832.
} 
Condition specific to the duration of the contract and the time for the conclusion of the contract:

Some jurists specify that the contract should be concluded before the fruit has begun to ripen, but others disagree ${ }^{35}$. The reason is that the labor of the worker has no role to play once the fruit has ripened.

\section{Conditions that render the contract void:}

The major stipulations that render to the contract that void are the giving of the entire yield to one party, or the stipulation of the share in known quantities, the stipulation of work for the owner of the trees, or the stipulation of transportation and storage after the division for the worker ${ }^{36}$.

\section{The ahkam (legal effects) of the contract:}

Musaqah is a binding (lazim) contract, and according to Malik it may be inherited ${ }^{37}$. Whatever work is required on the trees is the liability of the worker, and whatever expenditure is required is to be borne by the trees and thus to be shared by the parties in proportion to their shares ${ }^{38}$. If the trees do not produce anything then none of the parties is entitled to anything in the shape of lost wages or rent. The worker does not have the right to sub-let his tenancy to another, unless the owner permits him $^{39}$.

In the case of a vitiated (fasid) contract, the worker is not to be forced to perform the contract with' work. The entire yield will belong to the owner and the worker will be entitled to reasonable wages. The wages will be given even if the trees produced nothing, unlike a valid contract ${ }^{40}$.

\section{Rescission of the contract:}

The rules are the same as, those for muzara'ah, and the reason for this could be that the worker is a thief and so $\mathrm{on}^{41}$. The contract is rescinded due to the death of either party as in the case of muzara'ah.

Part (4) Legal framework of share cropping and irrigation according to provisions of Islamic Acts of Sudan Business Law of Transaction, 1984.

With reference to provisions of Sudan Islamic Act of Transaction. The code implied the provisions of renting the lands for the purpose of agriculture pursuant section (322-328). While the provisions that governing the contract of muzara'ah stating pursuant section (329-336). Moreover provisions that organizing contract of muzaqah included due to section (337-347). Notwithstanding the above mentioned contracts of partnership the code provides an other partten of partnership which called Muzarah according to for example: Section (322) in respect definition of offering a land for cultivation. Section (324) in respect of renting the land for cultivation to include the agric apparatus such as tractor, plough, reapers and others, section (328) governing the case of impossibility of proceeding the contract. Section (330) pertaining conditions for validity of muzara'ah. Sections (332), (333) pertaining the obligations of the two contractual parties. Sections (334- 336) pertaining the cases of termination of Muzara'ah.

\footnotetext{
${ }^{35}$ lbnRushd, Bidayat al-Mujtahid, vol. 2, p. 249.

${ }^{36}$ Loe. cit.

${ }^{37}$ Ibn Rushd, Bidiiyat al-Mujtahid, vol. 2, p. 250; al-Kasam, Bada'i' al-Sano'i', Vol. 8, P. 3835

${ }^{38}$ AI_Kasam, Bada'i' al-\$ana'i', vol. 8, p. 3834.

${ }^{39}$ Ibid. p. 3835.

${ }^{40}$ Ibid. 3836.

${ }^{41}$ Ibid. p. 3837.
} 
In addition section (337-340) in respect of definition and conditions for validity to contract of Musaqat. Section (341) governing the liability and the contractual party who will afford musaqah charges, while sections (344-346) stating the circumstances that terminate musaqat. And finally section (348) implies for definition of mugharasah (taking care of plants) and its provisions as method of partnership.

\section{Part (5): The role of Islamic bank in respect of practicing Muzara'ah and Musaqah in Nigeria:}

In most cases it is the same companies or employees who signed the contract of irrigation will undertake the responsibility of sharing crops. Normally the items of the contract stating the obligations of both contractual parties, fore example the bank will finance the charges of purchasing the improved seeds, fertilized, cost of farming, purchasing tractors, ploughs, harvesters machines, paying to the employees to harvest the crops or picking the fruits or vegetables. The agreed contract may state the duration of irrigation the nature of activities that done by employees. Moreover the governing contract will state the responsibilities of the farmers either they are the owners of agricultural projects or domestic rural cultivator. In addition the ratio of distribution of profits or affording the loss should be well constructed.

\section{Muzara'ah Financing:}

Financing real activities using the partnership mode of contract is vital in Islamic finance and economics. As such, the parties involved will bear the risk and share profit or loss that result from the business. Islamic financial principles lay much emphasis on participatory form of partnership. There are many modes of financing agriculture using the Islamic modes of finance. Kahf and Fahim (1992) identify the following principles that can be used to finance agriculture.

1. Participatory based financing which involves the principles of sharing profit or loss associated with the production or sharing the output. This principle can take the form of muzara'ah or musaqat.

2. Leasing based financing that involves the leasing of agricultural equipment to farmers on deferred payment. The financial institution can lease this equipment from the leasing company with cash and lease it to the farmers on deferred bases. At the end of the leasing period, the farmers has the option to either buy the equipment or return it to the bank ${ }^{42}$.

\section{Model Specification:}

By integrating the Muzara'ah model and supply chain mechanism, a unique characteristics have emerge vis-à-vis the strength of each model coming together produces a viable and alternative model. The major components of this model are the farmers and the financial institutions. The model is presented in Figure (1).

\section{i. Financial Institution}

the financial institution enters into muzara'ah contract with the farmers by providing funds meant for farming activities and share the crop outcomes based on agreed proportion. In the traditional Muzara'ah model, the role of the financial institution stops at this level. In the Muzara'ah- supply chain model, the financial institution is a partner, in addition to the provision of funds for procurement of seeds and chemical, it also ensures that other support services that facilitate supply chain such as efficient transportation and storage equipment are in place to maximized profit by reducing wastage.

\footnotetext{
${ }^{42}$ Moussa Larbani, Mustafa Omar, Mohammad and OladokunNafiuOlaniyi (2013): The Problems Facing the Agricultural Sector in Nigeria and the Prospect of Muzara'ah\& Supply Chain Model, Chapter 23, Edited in a book Essential of Islamic Banking and Finance in Nigeria, edited by K.I. Dandago A.D. Muhammad and U.O Useni, p359.
} 
In addition to this, financial institution will also regularly monitor the activities of the farmers and provide agricultural expertise and support through its agricultural division; it will also provide micro and macro economic data related to the sector and predictions about prices, demand (marketing expertise) and markets dynamics. See Figure (1) for more details. The financial institution has to do this because the farmers are its partners; its contract with the farmers is based on profit and loss sharing. It has to do all these in order to avoid losing their investment. In such a model the relation between the financial institution and the farmers is no more debtor- creator, it is a partnership, a model that requires coordination and cooperation.

\section{ii. Farmers}

The farmers also agree to enter into muzara'ah contract with the financial institution by contributing in the form of labor and/ or land and sharing the crops output based on agreed proportion. The farmers are responsible for growing, maintaining the crops and selling them to customers or industries that use them as their inputs. The farmers are also required to provides actual qualitative and quantitative data on their activities and production, report any problem on time. They have to do this in their own interest and because the financial institution is their partner not their creditor ${ }^{43}$.

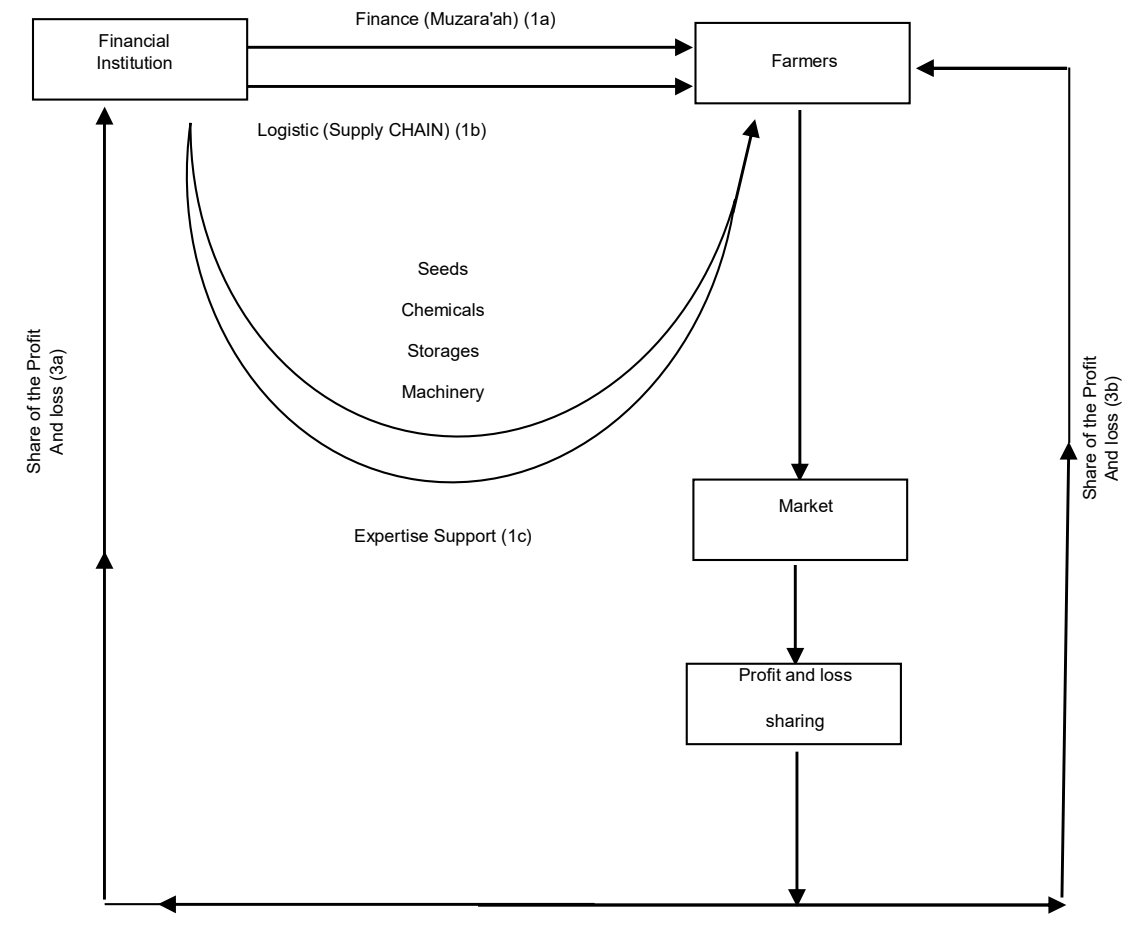

Figure 1: Muzara'ah- Supply Chain Model

Source: The Problems Facing the Agricultural Sector in Nigeria and the Prospect of Muzara'ah\& Supply Chain Model by: Moussa Larbani, Mustafa Omar, Mohammad and Oladokun Nafiu Olaniyi, p364.

${ }^{43}$ Ibd. pp362-363. 


\section{Below are the details explanations of the above model:}

1. The Financial institution enters into partnership contract with the farmer(s) to provide financing for procuring the necessary inputs and logistic related to agriculture (see 1(a), 1(b) \& 1(c) and the farmers contribute in form of labour (and or land). The financial institution provides agricultural, managerial and marketing expertise, and micro and macro data.

2. After harvesting, the products are delivered to the markets with the logistic support from the financial institution.

3. The profit/ loss from the sales will then be distributed between the two parties based on agreed profit and loss sharing ratio (see 3(a) and 3(b). The capital can be re-invested again depends on the agreement between the parties concern.

Table 1:Total imports and exports value base period quantity $(\$ 1000)$

\begin{tabular}{|l|l|l|}
\hline \multicolumn{1}{|c|}{ Year } & \multicolumn{1}{|c|}{ Import } & \multicolumn{1}{c|}{ Export } \\
\hline $1961-1970$ & 501,746 & $162,493.5$ \\
\hline $1971-1980$ & $1,855,175.8$ & $519,008.7$ \\
\hline $1981-1990$ & $1,935,976.8$ & $607,105.1$ \\
\hline $1991-2000$ & $1,373,853$ & $429,485.4$ \\
\hline 2001 & $1,219,346$ & 417,227 \\
\hline 2002 & $1,311,898$ & 373,491 \\
\hline 2003 & $1,650,403$ & 619,089 \\
\hline 2004 & $1,609,048$ & 497,307 \\
\hline 2005 & $1,662,270$ & 586,039 \\
\hline 2006 & $1,874,645$ & 519,253 \\
\hline
\end{tabular}

Source: FAOSTAT (28 April, 2009)

\section{i. Implications of the Model}

The significance of the Muzara'ah- supply Chain Model are four fold namely:

1. Firstly, it is expected that, the implementation of muzara'ah and the supply chain principles will enhance financial accessibility and increase the income of the farmers through improved market link.

2. Secondly the application of the model will help to encourage the spirit of partnership thereby reducing interest model of dealing.

3. Thirdly, more people will be attracted in the farming business since the access to finance and the link to the market that will help them sell their products at competitive price will be possible.

4. Fourthly, it will help in reducing poverty in the society. In addition to the above, it is assumed that the model will benefit the various sections of the society ${ }^{44}$.

${ }^{44}$ Ibd. Pp366-367. 
Business, Politics, Law \& Technology

Vol 6, No 2, June, 2020

\section{CONCLUSION}

Is expected to imply the following findings (1) Sharing corps is a contract allowed within Hanbali School of thought and in the view of Abu Yousuf and Mohammed bn Al-Hassan Alshybaini. (2) for the validity of share cropping conditions of: The land that should be cultivated, the seeds, the employees, the profit and the duration of the contract should be well stated. (3) Share cropping could be valid or vitiated. (4) The contract of Musagat or irrigation will be formed by offer and acceptance. (5) Contract of irrigation is handling tree to workers for purpose of irrigation or harvesting. (6) Contract of Musagah and Muzarah sharing the same conditions. (7) Both of the contracts bearing the same reasons of void or invalidity.

The Recommendations:It is recommended recommend the concern academic area of knowledge in particular Department of: economics, banking and finance, law, Islamic Sciences, Business and Management to include the Islamic methods of investment in business, in their curriculums and syllabus at both undergraduate and postgraduate levels. 


\section{REFERENCES}

1. Abdullahi Ibrahim Abikan (2013): The Legal Framework of Islamic Banking In Nigeria, chapter 7, edited in the book of Essential of Islamic Banking and Finance in Nigeria, edited by K.I. Dandago A.D. Muhammad and U.O Useni.

2. Al- Zailai, Usman bn Ali (1315H): Tabeyeen Al-Haqaiq SharhKanz Al-dagaig,vol(5), Al-matabah Alamyryah Al-kubra, Bawlag, first publication.

3. Ali Haidar (1991): Durar Al- Hukham SharahMajialat Al-Ahkam, translated by Lawyer Fahami Al-Hussaini, Dar aljjeel, Bairut, first publication.

4. Al-Kasani, Abubakar Bn Saud (2000): Bad iAlsanai Fi Tarteeb Al-Sharai,vol (8), Dar Al-ma'arifat, Bairut, first publication.

5. Al-Khrashi, Mohammed bn Abdallah (2006): Sharah El-Kharashi Ala MuktasarKhalili, Vol (6) Al-maktabah El-asryyah, Bairut, first publication.

6. Al-Marghinani, Burhanu Al-deen Abu Al-hassan (2002): Al-Hidayat Sharahbidayat Al-mubtadi, Vol (4), Dar Al-kutub Al-llimyat, Bairutfirst publication.

7. AtaulHaqPramanik (2009): Islamic Banking How Far Have We Gone, IIUM Press, Perpustakaan Negara; Malaysia.

8. E.S Ekezie (1997): The Elements of Banking Money, Financial Institution and Markets, Africana Feb Publisher Limited, Ibadan.

9. Essential of Islamic Banking (2013): Edited by K.I. Dandago, A.D. Mohammad and U.A Osaini, Benchmark Publishers, Kano.

10. Ibn Qudamat Al-magdisi, Al-duallahi Ahmed (1996): Al-mughni, Vol (5) Dar Hajar, Riyd, first Publication.

11. Ibn Rushud, Mohmmadbn Ahmed (1996): Bidayat Al-mujtahid, Vol (2), Dar Al-kutub Al- ilmiyatBairut, first publication.

12. Imran Ahsan Khan (1997): Islamic Law of Business Organization, Partnership, Published by International Islamic Institute of Thought, Islam Abad.

13. M.A. Mannan, A.K.M FazlulHoque and R.Z: Functions of an Islamic Banks, Chapter 9, Edited in the book of Islamic Banking How Far Have We Gone.

14. Mohammad Arafat (1319H): Hashya t Al-dasogi Ala Al-Sharah El-Kabair, Vol (3) Dar El-fikr, Bairut.

15. Moussa Larbani, Mustafa Omar, Mohammad and Oladokun NafiuOlaniyi (2013): The Problems Facing the Agricultural Sector in Nigeria and the Prospect of Muzara'ah\& Supply Chain Model, Chapter 23, Edited in a book Essential of Islamic Banking and Finance in Nigeria, edited by K.I. Dandago A.D. Muhammad and U.O Useni.

16. Musa Abdullahi (2013): Islamic Banks and Financial Institution in a Dual Banking System, Chapter 5, edited in a book Essential of Islamic Banking and Finance in Nigeria, edited by K.I. Dandago A.D. Muhammad and U.O Useni.

17. O.Y. Abdul (2013): Corporate Governance and Islamic Banking in Nigeria, Chapter 10, Edited in a book Essential of Islamic Banking and Finance in Nigeria, edited by K.I. Dandago A.D. Muhammad and U.O Useni.Oladokun Nafiu .

18. Olaniyi, Abdel Ghani Echchabi, Mohamad fany Alfarisi, (2013): Sukuk as An-Internative Mechanism for Infrastructure Development and Improvement of Small Business in Nigeria, Chapter 13, Edited in a book Essential of Islamic Banking and Finance in Nigeria, edited by K.I. Dandago A.D. Muhammad and U.O Useni.

19. Sahnun, bn Said El-tanukhi (2002): Al-mudawanah Al-Kubra, Vol (3) Naration of Mohammed Bn El-qasim, Dar Al-Kutub, Cairo. 